ROCZNIKI TEOLOGICZNE

Tom LXVII, zeszyt $9-2020$

DOI: http://dx.doi.org/10.18290/rt20679-11

MARIOLA TYMOCHOWICZ

\title{
DAR W OBRZĘDZIE NARODZINOWYM NA LUBELSZCZYŹNIE
}

\author{
A GIFT IN THE BIRTH RITE IN THE LUBLIN PROVINCE
}

\begin{abstract}
Gift giving in the birth rite in the past as well as today plays an important role, is one of his most important habits. The article presents situations in which the gifts were given, who was the recipient and what were and are the present forms of the gifts, as well as what they mean. The basis of the analysis are ethnographic materials from the Lublin region found and developed, obtained by the author, as well as from the archives of Lublin museums and the Archives of the Polish Ethnographic Atlas of Cieszyn.
\end{abstract}

Key words: birth rite; gift; traditional and contemporary culture.

Przyjście na świat dziecka w każdej społeczności jest ważnym wydarzeniem, zaliczanym do obrzędów włączenia, w którym następuje jego przyjęcie do rodziny, grona współmieszkańców lub wiernych. W tradycyjnej społeczności wiejskiej rytuał ten odbywał się podczas kilku pierwszych dni życia dziecka, z obawy przed grożącymi dziecku i matce niebezpieczeństwami ze strony złych mocy i demonów. Współcześnie mieszkańcy lubelskich wsi nie wierzą $\mathrm{w}$ tego typu zagrożenia oraz inne zwyczaje wcześniej praktykowane. Zapewne przyczyniło się to do wydłużenia nawet o kilka tygodni obchodów chrztu, stanowiącego ostatni etap tego obrzędu. Jak pisał H. Biegeleisen: „radość swą z powodu przybytku rodziny objawiano przed wiekami, jak obecnie za pomocą jedzenia i picia, tańca i podarków". Ten ostatni element rytuału, czyli obdarowywanie, będę chciała w niniejszym tekście szerzej przeanalizować, ukazując jak duże miało i nadal ma znaczenie w obrzędzie narodzinowym. Pod-

Dr hab. MARIOLA TYMOCHOwicz - adiunkt Instytutu Nauk o Kulturze Uniwersytetu Marii Curie-Skłodowskiej w Lublinie; e-mail: mariolate@wp.pl; https://orcid.org/0000-0002-3808-2326.

${ }^{1}$ Henryk, BIEGELEISEN, Matka i dziecko w obrzędach, wierzeniach i zwyczajach ludu polskiego (Lwów: Nakładem towarzystwa wydawniczego »Ateneum«, 1927), 225. 
stawę analizy stanowią etnograficzne materiały zastane i wywołane, pozyskane przez autorkę w latach 2004-2009 i 2018-2019 oraz pochodzące $z$ lat sześćdziesiątych i osiemdziesiątych wywiady przechowywane w archiwum Muzeum Lubelskiego (AML), Muzeum Wsi Lubelskiej (AMWL) i Archiwum Polskiego Atlasu Etnograficznego z Cieszyna (APAEwC) ${ }^{2}$.

W czasach przedchrześcijańskich , celem przebłagania złych duchów, a następnie jako podziękę i prośbę dobroczynnego bóstwa, składano od niepamiętnych czasów ofiary i odprawiano modlitwy z powodu przyjścia nowego przybysza na świat"3. W kolejnych wiekach zaniechano w Polsce tego typu zwyczaju, ale darzenie pozostało, zmianie uległ jego adresat, stał się nim główny bohater obrzędu, czyli osoba poddawana inicjacji - dziecko, a także matka, babka (wiejska akuszerka) oraz pozostali goście uczty chrzcinowej. Przekazanie daru było i jest jedną $\mathrm{z}$ istotnych czynności obrzędowych o znaczeniu symbolicznym, „ma zawsze charakter rytualny, związany jest ściśle z sytuacją, w której się dokonuje, a darem samym jest rzecz, poczęstunek oraz słowo" ${ }^{4}$ W tradycyjnych społecznościach poprzez symboliczną wymianę tworzyła się między ludźmi nierozerwalna więź. Dawanie traktowane było jako pierwotna zasada wszelkich kulturowych kreacji więzi międzyludzkich ${ }^{5}$, ponieważ obdarowywanie „mieści w sobie nie tylko obowiązek odwzajemniania darów otrzymanych, lecz nadto zakłada dwa inne, równie ważne: z jednej strony, obowiązek dawania podarunków, z drugiej obowiązek przyjmowania ich”. „Wymiana darów w tym kontekście nie jest tylko grzecznością, ale jedną z podstawowych reguł współżycia"7. Przyczyniała się do powstania sieci zobowiązań, współpracy, współodpowiedzialności, pozyskania wpływów, ale również podtrzymywania nakazanych tradycją zwyczajów, które wymagały składania darów w określonych sytuacjach obrzędowych i okolicznościowych. Przekazywanie darów stawało się transakcją zawieraną między poszczególnymi

\footnotetext{
${ }^{2}$ Przy cytowanych transkrypcjach zastosowany został zapis półfonetyczny z zachowaniem wymowy gwarowej, a przy kodowaniu danych respondentów przyjęto zasadę zapisu: miejscowość, powiat, inicjały imienia i nazwiska, płeć i rok urodzenia.

${ }^{3}$ Biegeleisen, Matka i dziecko, 221.

${ }^{4}$ Róża Godula, Od Mikołaja do Trzech Króli. O roli daru w obrzędzie (Kraków: Wydawnictwo Wawelskie, 1994), 10.

${ }^{5}$ Anna ZADrożYŃSKA, Światy, zaświaty. O tradycji świętowań polskich (Warszawa: Wydawnictwo Książkowe Twój Styl, 2000), 61.

${ }^{6}$ Marcel Maus, Socjologia i antropologia, przełożyli Marcin Król, Krzysztof Pomian, Józef Szacki (Warszawa: PWN, 1973), 228.

${ }^{7}$ Jan ADAMOWSKI, Ludowe sposoby składania życzeń (słowo w kontekście kultury), seria: Język a kultura, t. 6: Polska etykieta językowa, Wiedza o Kulturze, red. Janusz Anusiewicz, Małgorzata Marcjanik (Wrocław: Wiedza o Kulturze, 1992), 103.
} 
osobami lub całą grupą i służyło pozyskiwaniu wartości pozaekonomicznych. $\mathrm{W}$ ten sposób dar, definiowany za pomocą wartości wyobrażonych (symbolicznych), pozostaje aktem całościowym społecznie, służy utrzymaniu bądź kreowaniu nowej rzeczywistości i więzi społecznej ${ }^{8}$.

Przekazywanie daru było zawsze skonwencjonalizowane, jak większość zachowań mieszkańców tradycyjnej wsi ${ }^{9}$. Pełni ono „funkcję magiczną, może być znakiem zaproszenia, zgody, odmowy, jego forma może informować o pozycji społecznej ofiarodawcy, czy też o stopniu jego pokrewieństwa $\mathrm{z}$ obdarowanym" ${ }^{10}$. Podczas obrzędowego obdarowywania znaczenie miały działania o charakterze rytualno-magicznym, a także kto komu przekazuje dar, kiedy i gdzie dochodziło do obdarowania, co było przedmiotem daru, jaka była forma wręczania i przyjmowania, a także co należało wypowiadać w takim momencie oraz jakiego rodzaju korzyści strony biorące w tym udział miały zyskać z tej szczególnej formy transakcji. Tak też było i nadal jest podczas realizacji rytuału narodzinowego.

Pierwsza forma obdarowywania rozpoczynała się w przeszłości w kilka godzin po porodzie, kiedy do domu położnicy, gdzie odbywał się poród, zaczęły się schodzić krewne i najbliższe sąsiadki na tak zwane odwiedziny, to so normalnie z całej wsi po prostu takie koleżanki. Kiedyś to było inaczej, kiedyś tośmy same kobiety się schodzity na odwiedziny ${ }^{11}$. Był to zwyczaj praktykowany od czasów przedchrześcijańskich i powszechny na terenie całej Słowiańszczyzny i u innych ludów indoeuropejskich, na Węgrzech, w Estonii. Pierwotnie miał on zapobiegać niebezpieczeństwu grożącemu położnicy i jej dziecku ze strony złych mocy ${ }^{12}$. Z czasem była to wizyta, w trakcie której kobiety winszowały matce nowego potomka, przekazywały jej rady oraz dary. Było to jedyne usankcjonowane spotkanie, respektowane w okresie izolacji obrzędowej

\footnotetext{
${ }^{8}$ Piotr FrAnKe, „Dar”, w Przeszłość społeczna próba konceptualizacji, red. Stanisław Tabaczyński, Arkadiusz Marciniak, Dorota Cyngot, Anna Zalewska (Poznań: Wydawnictwo Poznańskie, 2012), 783.

${ }^{9}$ Zofia SzROMBA-RysowA, „Zwyczaje towarzyskie, zawodowe i okolicznościowe”, w Etnografia Polski. Przemiany kultury ludowej, t. 2, red. Maria Biernacka, Bronisława KopczyńskaJaworska, Anna Kutrzeba-Pojnarowa, Wanda Paprocka (Wrocław: Ossolineum, 1981), 160.

${ }^{10}$ Małgorzata MAJ, Rola daru w obrzędzie weselnym (Wrocław-Warszawa-Kraków-GdańskŁódź: Ossolineum, 1986), 6.

${ }^{11}$ Kolembrody, pow. radzyński, U.Z., kobieta, ur. 1940 r.

${ }^{12}$ Biegeleisen, Matka i dziecko, 217. „Kobiecie nie wolno było nigdzie iść przed wywodem. Nieczynna była, nie wolno jej było, gdzie pójść ani co robić, ani z kim rozmawiać, bo była jeszcze niepobłogosławiona", Flisy, pow. janowski, AMWL/640.
} 
położnicy ${ }^{13}$. Matce w różnych stronach „Polski i Rusi znoszono w darze zboże, ziemniaki, groch, bób, jaja, ser, sól, kasze, mleko, masło itp. A ona odbierając te dary, częstuje ich wódką kosmatą (zaprawną miodem) itp. Podczas obdarzania odbywa się składanie życzeń i błogosławieństwo położnicy i dziecka" ${ }^{14}$. Otrzymane produkty spożywcze lub gotowe potrawy miały wzmocnić osłabioną porodem gospodynię i były przeznaczone dla pozostałych członków rodziny, gdyż ona nie była w stanie przygotować im posiłków. Przyniesiona żywność stanowiła istotne świadczenie i wsparcie zwłaszcza dla rodzin ubogich.

Szczególnym rodzajem daru w opisywanej sytuacji obrzędowej były wygłaszane przez przybyłych życzenia i błogosławieństwo ${ }^{15}$. Ponieważ w „tradycyjnej kulturze ludowej inny jest generalnie status wypowiedzi życzeniowych. Nie mają one tam charakteru zewnętrznego, dekoracyjnego, a są niezbywalnym elementem zachowań na równi z czynnościami. W folklorze bowiem słowo i działania równoważą się całkowicie" ${ }^{16}$. Wypowiedziane życzenia nabierały mocy sprawczej i kreatywnej ${ }^{17}$, gdyż przekazywane były w „kontekście obrzędowego sacrum i postawy magicznej charakterystycznej zarówno dla nadawcy jak i odbiorcy" ${ }^{\prime 1}$. Za wszystkie te formy daru i wsparcia gospodyni odwdzięczała się poczęstunkiem z alkoholem.

Podczas pierwszej wizyty pamiętano także o dziecku, jak tłumaczyła jedna z respondentek: No kiedyś do Pana Jezusa dary nieśli, tak to się przyjeło, że jak się dziecko urodzi, to też trzeba go obdarować czyms' ${ }^{19}$. Nie można było przyjść z gotymi ręcami, tylko musi coś wziąć i tam zanieść dla dziecka ${ }^{20}$. Odwiedzające kobiety wręczały najczęściej chleb, żeby to dziecko miało, chleba nie brakło

\footnotetext{
${ }^{13}$ Barbara Ogrodowska, Polskie tradycje i obyczaje rodzinne (Warszawa: Wydawnictwo Muza, 2007), 44.

${ }^{14}$ BiEgeleisen, Matka i dziecko, 216.

${ }^{15}$ Anna DomagaŁA, „Problematyka aktu błogosławieństwa w językoznawstwie i etnolingwistyce", Ślaskie Studia Historyczno-Teologiczne nr 45/1 (2012): 110.

${ }^{16}$ ADAMOwSKI, Ludowe sposoby składania życzeń, 98.

17 „Nie ma więc winszowania komuś (czegoś) przy lada okazji. Dodać też trzeba, że słowo często pozostaje elementem niesamodzielnym w komunikacie życzeniowym, dlatego formuły werbalne bywają całkowicie zastępowane symbolicznym gestem, przewidzianym w kulturowym skrypcie danego zwyczaju czy obrzędu (obsypywanie owsem, wiązanie powrósłem, składanie daru, stawianie «maja» dziewczynie, czynienie znakukrzyża, kropienie wodą święconą, polewanie wodą, wypicie alkoholu itp.)”, za: Kazimierz SiKORA, „Winszowanie i dobre słowo w gwarze”, Annales Universitatis Paedagogicae Cracoviensis Studia Linguistica 107, nr 6 (2011): 177.

${ }^{18}$ Jan ADAMOwski, Współczesne życzenia świateczne z okazji Bożego Narodzenia i Nowego Roku, dostęp: 20.03.2020, http://zgstl.netstrefa.pl/k1_old/widok/219/1886.html

${ }^{19}$ Gęsia Wólka, pow. rycki, JB, kobieta, ur. 1937 r.

${ }^{20}$ Wyryki, pow. włodawski, S.S., kobieta, ur.1930 r.
} 
$m u^{21}$ a chleb, żeby byt zawsze bogaty $w \dot{z} y c i u$, chleba mu nie brakowato ${ }^{22}$, a także cukier, aby miało słodkie życie, żeby to dziecko zawsze miało dostatek ${ }^{23} \mathrm{w}$ życiu. Dawano też mydło, żeby się myło, całe życie, czyste takie miało swoje. Tak kasze, mąki kiedyśs się nosito, no to tak już nawet te kobiety ze wsi przychodzili jedna tam, drugie to niosty na takie odwiedziny dziecka. To, żeby miało co jeść, żeby mu nie brakło. No to takie byty zwyczaje kiedyśs ${ }^{24}$. Nosito się troche jakiegoś tam plótna, żeby to se ta matka tych piluch zrobiła ${ }^{25}$. W niektórych miejscowościach była przestrzegana zasada, żeby jak do dziecka, jak się idzie, że trzeba zanieść coś żywego. No to na przykład, no kura, na przykład może być kogut. Ale niektórzy twierdza, że koniecznie żywych. Choć akurat tam, gdzie to dziecko urodzone sa niezadowoleni może $z$ tego. Ale wtaśnie dlatego, żeby to dziecko byto żywe. Żywe byto, żeby takie byto no zdrowe $i$ w ogóle to, żeby to byt zdrowy jakiś dorodny kogut czy kura ${ }^{26}$.

Głównym darem dla dziecka był wówczas chleb, przynajmniej kawałek ${ }^{27}$, który jest symbolem dobrobytu, darem od Boga mającym zapewnić mu dostatnie, spokojne i bezpieczne życie ${ }^{28}$. Powszechnie wierzono także, że „chleb miał moc odwracania złych, nieczystych mocy od położnicy i niemowlęcia" ${ }^{29}$. Odgrywał on tym samym ważną rolę w rytuałach recepcyjnych, które decydowały o przyjmowaniu do wspólnoty, miał zapewnić szczęście i chronić przed przeciwnościami losu ${ }^{30}$. Równie ważnym i częstym darem był cukier, wprowadzony prawdopodobnie na przełomie XIX i XX wieku, ceniono go, bo nabywany był za gotówkę, której dawniej nie posiadano w nadmiarze, a jego właściwości zapewnić miały słodkie i dobre życie.

Współcześnie zachował się zwyczaj odwiedzania matki i dziecka po ich powrocie ze szpitala. Przychodzą wówczas członkowie najbliższej rodziny, koleżanki, którzy przeważnie tak z prezentem. Kupuje się maluszkowi jakieś ubranko, upominek i po prostu no przyjmuje sie gościa przy kawie, herbacie. I bardzo fajnie to ${ }^{31}$. Przynoszone prezenty dla dziecka to zazwyczaj czekolada,

\footnotetext{
${ }^{21}$ Zawieprzyce Kolonia, pow. łęczyński, E.K., kobieta, ur. 1925 r.

${ }^{22}$ Zarudzie, pow. zamojski, I.B., kobieta, ur. 1949 r.

${ }^{23}$ Kocudza, pow. pow. janowski, A.M., kobieta, ur. $1951 \mathrm{r}$.

${ }^{24}$ Jezioro, pow. parczewsk, Cz.S., kobieta, ur. $1941 \mathrm{r}$.

${ }^{25}$ Blinów II, M.K., pow. kraśnicki, kobieta, ur. $1941 \mathrm{r}$.

${ }^{26}$ Piotrków, pow. lubelski, S.M., kobieta, ur.1951 r.

${ }^{27}$ Wirkowice, pow. krasnostawski, APAEwC 35/30/IV.

${ }^{28}$ Władysław KopAliŃsKi, Stownik symboli (Warszawa: Wiedza Powszechna, 1990), 41-43.

${ }^{29}$ Biegeleisen, Matka i dziecko, 223.

${ }^{30}$ Piotr KowALSKI, Chleb nasz powszedni. O pieczywie w obrzędach, magii, literackich obrazach i opiniach dietetyków (Wrocław: Towarzystwo Przyjaciół Ossolineum, 2000), 125.

${ }^{31}$ Kolonia Grabów Szlachecki, pow. Łęczna, N.N., kobieta, ur. 1974 r.
} 
czyli zamiennik wcześniejszego cukru, a także zabawki, pieluchy i pieniqżek, żeby nie brakło pieniażków, pod główkę się kładto ${ }^{32}$. Praktyczne prezenty wykorzystywane są do opieki nad dzieckiem, a pieniądze przeznaczane na zakup innych brakujących rzeczy, albo wpłacane są na specjalne konto założone dla dziecka, z przeznaczeniem na przyszłość.

W drugiej połowie XX wieku rozpowszechnił się na Lubelszczyźnie także zwyczaj obdarowywania matki przez męża, co stanowi formę podziękowania za urodzenie dziecka. Początkowo były to drobne prezenty w postaci kwiatów, tekstyliów, np. chustka, bluzka, a w ostatnich latach jest to często biżuteria. Jak wspominała jedna z respondentek: $W$ mojej rodzinie to byto. To znaczy, jak ja rodziłam tak. Urodziłam, na urodziny córki dostałam naszyjnik od męża. A na urodziny syna dostałam pierścionek złoty. Tak, tak pamiętam, jak mama moja zawsze wyciagata taka chustke na głowe. I pamiętam ja tak jakby to było dzisiaj, bo już bytam dosyć duża i zawsze byto: „Marysiu zobacz ta chusteczke, to mi kupit tata jak ty się urodzitaś". No to byta taka biała chustka kretonowa, bo wtedy byty takie czasy i miała bardzo drobny szlaczek czarny $z$ takich czarnych kwiatuszków ${ }^{33}$. Zwyczaj ten jest nadal utrzymany i powtarzany przy narodzinach każdego dziecka.

Odwiedzanie położnicy obowiązuje, szczególnie najbliższa rodzinę, a także sasiadki i najbliższe przyjaciółki. Ona u mnie była, to i ja do ni muszę iść ${ }^{34}$. Ta sytuacja bardzo wyraźnie ukazuje, że dar musi być odwzajemniony. W tym przypadku matka od razu się odwdzięczała poczęstunkiem, ale to, co otrzymywało dziecko, należało oddać, kiedy jedna z odwiedzających wówczas kobiet urodzi dziecko. Ta zasada jest też powszechnie współcześnie przestrzegana, $\mathrm{z}$ tą różnicą, że zmieniły się formy prezentów, nie jest to już jedzenie, bo nie stanowi ono już tak dużego znaczenia jak dawniej. Teraz są to prezenty rzeczowe, których wartość często zależna od bliskości pokrewieństwa lub przyjacielskich relacji z rodzicami.

Kolejny moment darzenia następował przed wyjściem do Kościoła na mszę, podczas której udzielany był dziecku sakrament chrztu. Dawniej przybyli do domu rodzice chrzestni, nazywani kumami, wręczali dziecku specjalne podarki. Kum dawat monetę, która wktadat do becika dziecku, żeby byto zamożne. Kuma dawała kawatek biatego płótna, które kładziono na beciku dziecku w czasie chrztu. Dawała też koszulki, żeby dziecko nie niszczyło ubrań, żeby nie było

\footnotetext{
${ }^{32}$ Jezioro, pow. parczewski, Cz.S., kobieta, ur. 1941 r.

${ }^{33}$ Blinów II, pow. kraśnicki, M.K., kobieta, ur. 1941 r.

${ }^{34}$ Przewłoka, pow. parczewski, APAEwC 35/25/XIV.
} 
biedne $e^{35}$. Dla zabezpieczenia, „gdy dziecię mają wynieść do chrztu, babka lub matka kładą mu w pieluszki - małą skrajkę chleba i ząbek czostku (czosnku) na ten cel, aby nowo narodzonego chleb się trzymał, a czosnek oddalał wpływ złego ducha, w czasie, gdy będzie niesione do chrztu" ${ }^{36}$. Powszechnie uważano, że czosnek ${ }^{37}$ posiadał właściwości odstraszające złe duchy ze względu na swój niemiły zapach, stosowany był przeciw urokom i używany jako talizman ${ }^{38}$. W miejscowości Dąbrówka, pow. Biłgoraj, do becika wkładano pod główkę kawatek chleba, żeby nie byto w życiu głodne, papier zapisany, żeby się dobrze uczyto, pieniądze, żeby było bogate i obrazek święty, żeby byto pobożne ${ }^{39}$. W Piotrkowie, Tuszowie, Wojcieszkowie przypinano do ubranka dziewczynki nitkę z igłą, aby dobrze szyła ${ }^{40}$. Dary te miały oddziaływać i zapewnić dobrą przyszłość dziecku. Były też takie, jak np. chleb, których celem była ochrona noworodka - w czasie drogi do kościoła, przed niebezpieczeństwami, jakie groziły mu będąc $\mathrm{w}$ fazie zawieszenia. $\mathrm{W}$ ostatnich latach w niektórych miejscowościach chrzestny to jakaśs pamiatkę $i$ zazwyczaj to chrzestny kupuje świece. To zależy, jak się tam ustala, bo czasem kupuje i chrzestna, ale chrzestna i tak ma już taki większy wydatek, bo ubrać dziecko, no to dla chrzestnego świeca, upominek, tańcuszek ${ }^{41} \mathrm{z}$ medalikiem lub krzyżykiem kupują. Współcześnie coraz częściej rodzice sami kupują ubranko dla dziecka i inne rekwizyty potrzebne podczas chrztu, a chrzestni na pamiątkę oprócz wspomnianej biżuterii, przynoszą Biblię dla dzieci, specjalne pamiątki dedykowane na chrzest (np. srebrny obrazek lub szklana statuetka z grawerem, pozytywki, pudełka wspomnień, sztućce, albumy na zdjęcia,

\footnotetext{
${ }^{35}$ Paszki Duże, pow. radzyński, APAEwC 33/25/VIII.

${ }^{36}$ Oskar Kolberg, Dzieła wszystkie. Chetmskie, t. 33, cz. 1, 1964, [wyd. fotoofset. z: Chetmskie. Obraz etnograficzny skreślił..., t. 1, 1890], 175.

${ }^{37}$ Czosnek u wszystkich Słowian oraz u wielu innych ludów „uchodził za broń zupełnie bodaj wszechstronną, zabezpieczać ma bowiem nie tylko od demonów, zmor, czarownic itp., lecz również od wszelkich w ogóle czarów oraz - i to przede wszystkim - od uroków”, za: Kazimierz MoszyŃsKi, Kultura ludowa Stowian, t. II cz. 1 (Kraków: Książka i Wiedza, 1967), 330. Noszony był przez wiele osób, bądź wcierano go w ciało. Był on także wykorzystywany w celach leczniczych, zob. Stownik stereotypów i symboli ludowych, red. Jerzy Bartmiński, t. 2: Rośliny, cz. 2: Warzywa (Lublin: Wydawnictwo UMCS, 2018), 282-294.

${ }^{38}$ Vitalij ŽaJVORONOK, Znaki ukrajins'koji etnokul'turi. Slovnik-dovidnik (Kijiv, 2006), 363.

${ }^{39}$ Archiwum Polskiego Atlasu Etnograficznego w Cieszynie: Dąbrówka, pow. biłgorajski, 34/32/XIII.

${ }^{40}$ Mariola Tymochowicz, Lubelska obrzędowość rodzinna $w$ kontekście wspótczesnych przemian (Lublin: Lubelskie Towarzystwo Naukowe, 2013), 70.

${ }^{41}$ Piotrków, pow. lubelski, G.A., kobieta, ur. $1951 \mathrm{r}$.
} 
srebrna grzechotka ${ }^{42}$ ), ale też wręczają rodzicom pieniądze, aby nabyli potrzebne rzeczy dla dziecka.

Oprócz prezentu dla niemowlęcia, dawniej chrzestna była zobowiązana obdarować również jego matkę, o czym wspomina jedna z respondentek: I kiedyś nie byto tak, że kumy wybierali kumów obcych catkiem ludzi. Tylko on takich zaufanych, może dobrych ludzi, żeby to dziecko brało przykład z tych chrzestnych. I byta już szła na te chrzciny matka, ta chrzestna, chrzestny i kupowali prezent. Matce kupowali, dziecko ubierała, ale i matce kupowała. Czy na bluzke, czy chustke jakaś ładna i jak to już po chrzcinach za tydzień czy za dwa tygodnie to ta matka dziecka przychodziła do tej kumy swojej i też dla niej odnosiła prezent. Kupywała coś jakąś też chusteczke, różnie chustki, czy szalinówka. I już przychodziła do tej kumy swojej i już takie było no kumostwo już tak się robiło $^{43}$. Taka forma wymiany darów miała na celu zacieśnienie więzi między kobietami, które przez tak zwane kumostwo stawały się sobie bliższe. Przyjęcie roli rodzica chrzestnego zobowiązywało do zaangażowania się w życie dziecka i jego rodziców. Chrzestni na ile mogli, to w późniejszych latach wspierali chrześniaka drobnymi podarkami, np. pisankami w Wielkanoc, ale też uczestniczyli, nadal jest to zachowane, we wszystkich znaczących wydarzeniach w jego życiu, jak I Komunia Święta, osiemnaste urodziny czy ślub.

Ważnym gościem chrzcin, w pierwszych latach powojennych, była babka, która pomagała przy porodzie i opiekowała się matką w połogu i dzieckiem. Otrzymywała ona zapłatę od rodziców w wysokości jednego rubla lub w formie produktów spożywczych, np. miarkę zboża, parę garncy mąki lub kaszy, słoninę, chleb, a nadto od kumów po 4 grosze ${ }^{44}$. Oskar Kolberg udokumentowal, że babka podczas przyjęcia podchodziła „do każdego z chrzestnych gości, i również dopominając się »na mydło«, dostaje od nich po kilka groszy”"45. Darowizna ta stanowiła wsparcie dla rodziców, których nie było stać na opłacenie pracy babki.

Podobna forma pomocy występowała przy organizacji chrzcin, na które wszyscy jego uczestnicy przynosili dawniej produkty spożywcze, z których przygotowywano poczęstunek. We wsi Nabroż, pow. tomaszowski, „każdy kum w dzień chrztu przynosi rodzicom nowonarodzonego dziecka bochenek

\footnotetext{
${ }^{42}$ Sklepy internetowe proponują specjalny typ prezentów dla matki chrzestnej i chrzestnego, inne dla chłopca i dziewczynki, dostęp: 20.03.2020, https://prezentynachrzest.com/prezent_od_ matki_chrzestnej,c, 4461 .

${ }^{43}$ Jakówki, pow. bialski, M.O., kobieta, ur. 1942 r.

${ }^{44}$ Zofia STANISZEWSKA, „Wieś Studzianki”, Wisła 16, z. 4 (1902): 504-505.

${ }^{45}$ Kolberg, Chetmski, 176.
} 
chleba, a kuma - jajka, masło, ser i kawałek płótna $\left(\text { krzyżmo }^{46}\right)^{\text {, } 47}$, a „,we wsi Wierzchowiska pow. janowskiego zaproszeni rodzice chrzestni przynoszą na chrzciny po bochenku chleba, bo inaczej dziecko miałoby dorobek ciężki" ${ }^{48}$. W Dołhobrodach do tego domu, jak przychodzili na chrzciny zaproszeni goście, to musiała być pieczywa cała chusta. I to byla taka na cztery rogi zawiazana. Także już petna chustka tego ${ }^{49}$. I jeszcze trzeba byto ja od razu kłaść te pieczywo i rozwiazywać, żeby to dziecko rozwijato się szybko, żeby nie byto takie niedorozwinięte ${ }^{50}$. A kiedyś to ci co szli na chrzciny, bo pamiętam, jak moi rodzice szli na chrzciny, to tatuś brat wódke, a mamusia kietbase czy placek. I to byty chrzciny i schodzity się i to byty chrzciny. A teraz nikt tego nie bierze tylko rodzice przyszykowujo i to dajo prezenty ${ }^{51}$. Partycypowanie gości w poczęstunku było ogólnie przyjętą formą pomocy rodzinie, którą nie zawsze było stać na jego przygotowanie, a tego typu wsparcie pozwalało na rozłożenie kosztów na wszystkich jego uczestników. Przyjęcie zaproszenia i uczestnictwo w chrzcinach pociągało za sobą konieczność ofiarowania daru ${ }^{52}$, najczęściej w postaci jedzenia. Biesiada jest przecież ich nieodłącznym elementem, a brak daru mógłby sprawić, że niedopełniony byłby rytuał, a to, jak wierzono, przyniosłoby negatywnie skutki dla inicjowanej osoby, jak i całej społeczności. Przynoszenie jedzenia przyczyniało się również do zacieśniania więzi między rodziną oraz poszczególnymi członkami lokalnej społeczności. Tego typu dary nie wymagały od gospodarza uczty natychmiastowego odwzajemnienia, mogło ono nastąpić dopiero po latach, kiedy zaproszony był na któryś z obrzędów rodzinnych organizowanych przez swojego gościa.

Współcześnie zwyczaj wspierania rodziców ograniczony jest do przynoszenia na chrzciny ciasta przez najbliższą rodzinę czy sąsiadki, a pozostałe koszty związane z jego przygotowaniem ponoszą sami. Wspólny obiad z gośćmi stanowi formę podziękowania im za udział w obrzędzie oraz przyniesione przez nich prezenty dla dziecka.

W latach powojennych przyjął się zwyczaj, że zaproszeni goście zamiast jedzenia na przyjęcie przynoszą prezenty, np. zabawki, srebrne łańcuszki, a często

\footnotetext{
${ }^{46}$ Tak jest na Lubelszczyźnie nazywany kawałek materiału lub biała szatka, którą kładzie się dziecku na piersiach podczas sakramentu chrztu.

${ }^{47}$ Hieronim ŁOPACIŃSKI, „Obrzędy religijne i zwyczaje przy nich zachowane. Z materiałów nadesłanych na Wystawę rolno-przemysłową w 1901”, Wisła 16, z. 3 (1902): 358.

48 Tamże, s. 358.

${ }^{49}$ Dołhobrody, pow. włodawski, M.S., kobieta, ur.1939 r.

${ }^{50}$ Dołhobrody, pow. włodawski, K.D., kobieta, ur. 1939 r.

${ }^{51}$ Dąbia Nowa, pow. rycki, Z.W., kobieta, ur. 1945 r.

${ }^{52}$ Zofia SzRombA-RYSOwA, „Biesiady wiejskie”, Etnografia Polska 28, z. 1 (1984): 127.
} 
kartkę w kopercie, do której wkładane są pieniądze. Z tym, że jest to kartka przeznaczona na chrzciny lub samodzielnie zaprojektowana. Może być ona spersonalizowana, dedykowana dziewczynce lub chłopcu, $\mathrm{z}$ wpisanym imieniem dziecka i datą chrztu, a wewnątrz z samodzielnie zapisanymi lub drukowanymi życzeniami, np.:

Kruszynko,

z okazji Chrztu Świętego życzę Ci,

abyś zaznała wiele łask Bożych,

abyś była pociechą dla bliskich

i aby Bóg, który jest w niebie

zawsze miał Ciebie w opiece ${ }^{53}$.

Kartka taka stanowi pamiątkę, która jest przechowywana przez rodziców. Jest również zapisanym darem słowa, które świadczy o życzliwości ofiarodawcy.

Reasumując, w omawianym obrzędzie podtrzymane zostały do czasów współczesnych trzy momenty wręczania daru, czyli podczas odwiedzin matki i dziecka po narodzinach, przy przygotowywaniu dziecka do chrztu i na przyjęciu. W przeszłości głównymi odbiorcami darów, oprócz dziecka, była też matka i babka. Wszystkie przekazane dary były i są przyjmowane z wdzięcznością. Mają one nadal charakter rzeczowy, poczęstunku i słowa. Nastąpiły jednak zmiany co do rodzaju prezentów. Dawniej głównym darem były różnego rodzaju produkty spożywcze, które w szczególny sposób ceniono, gdyż często ich brakowało. Stanowiły one nie tylko wartość materialną, ale także sakralno-symboliczną. Przyjmowały formę, jak np. chleb, ofiary od Boga, środka apotropeicznego, a także wyraz wdzięczności czy zapłaty za udzieloną pomoc, życzliwość i słowa. Dla dziecka dary te miały znaczenie symboliczne, gdyż formalnie ich nie spożywało, ale chroniły go w czasie realizacji poszczególnych faz rytuału przejścia oraz według wierzeń ludowych zapewniały dobrą przyszłość. Do ważnego daru rzeczowego należało również krzyżmo, czyli materiał lniany, który był użyty podczas nabożeństwa, a później szyto z niego ubranka czy pieluchy dla dziecka. Stanisław Bystroń uważał, że nieprzypadkowo właśnie płótno było darem dla dziecka w tym obrzędzie, bo „odzianie go tem płótnem byłoby jednym z ogniw wielkiego łańcucha ceremonii przyjęcia do społeczności" ${ }^{54}$. Miało ono zatem tak symboliczne, jak i praktyczne zastosowanie. W ostatnich kilku dekadach znaczenie zyskały prezenty specjalnie przeznaczone na chrzest, które można kupić w sklepach z dewocjonaliami, jak biżuteria z medalikiem, książki i obrazki religijne, ale też jak podała

\footnotetext{
${ }^{53}$ Życzenia z kartki - Pamiątka na Chrzest.

${ }^{54}$ BYSTROŃ, Stowiańskie obrzędy rodzinne, 83.
} 
jedna z moich rozmówczyń: To znaczy każdy woli pieniądz. Bo przyniesie jeden tyle, drugi tyle. Zbierze sobie i kupi temu dziecku czy wózek, co tam komu pasuje. Ale przepraszam wózek przeważnie kupuje babcia, mama mamy ${ }^{55}$.

Kolejny rodzaj daru, czyli poczęstunek, nie jest już zwyczajowo wspierany przez gości, ale nadal stanowi ważny element obrzędu i formę podziękowania im za udział w obrzędzie i przyniesione prezenty. Zachodzi wówczas swoista wymiana darów, która jest wymagana w procesie obdarowywania. W tym przypadku odbywało się to w czasie realizacji obrzędu, ale za dary przyniesione dziecku po porodzie, następuje to dopiero po kilku tygodniach czy miesiącach, kiedy matka odwiedzając inną położnicę, przynosi podarki dla dziecka.

Natomiast słowo mówione, a ostatnio też pisane, pozwala przekazać życzenia zapewniające dziecku dobrą przyszłość, opiekę Boga, jest również okazją do wyrażenia pozytywnych uczuć nadawcy. Wszystkie te rodzaje darów i zasady ich wręczania nie są tylko formą grzecznościową, ale jedną z istotnych reguł współżycia społecznego, odnoszących się do uznanych w danej zbiorowości wartości i zasad obyczajowych. Tylko w niewielkim stopniu ulegają zmianom, co jest wymuszone ogólnymi przeobrażeniami cywilizacyjnymi, technologicznymi i kulturowymi.

\section{BIBLIOGRAFIA}

ADAMOwSKI, Jan. Ludowe sposoby składania życzeń (słowo $w$ kontekście kultury). Seria: Język a kultura, t. 6: Polska etykieta językowa, red. Janusz Anusiewicz, Małgorzata Marcjanik, 97-105. Wrocław: Wiedza o Kulturze, 1992.

ADAmowsKi, Jan. Współczesne życzenia świąteczne z okazji Bożego Narodzenia i Nowego Roku. Dostęp: 20.03.2020, http://zgstl.netstrefa.pl/k1_old/widok/219/1886.html.

BIEGELEISEN, Henryk. Matka i dziecko w obrzędach, wierzeniach i zwyczajach ludu polskiego. Lwów: Nakładem towarzystwa wydawniczego »Ateneum«, 1927.

BYSTROŃ, Jan Stanisław. Słowiańskie obrzędy rodzinne. Obrzędy związane z narodzinami dziecka. Kraków, 1919.

DomagaŁA, Anna. „Problematyka aktu błogosławieństwa w językoznawstwie i etnolingwistyce”. Śląskie Studia Historyczno-Teologiczne nr 45 (2012): 110-120.

Kolberg, Oskar. Dzieta Wszystkie. Chetmskie, t. 33, cz. 1, 1964, [wyd. fotoofset. z: Chetmskie. Obraz etnograficzny skreślił..., t. 1, 1890].

Godula, Róża. Od Mikołaja do Trzech Króli. O roli daru w obrzędzie. Kraków: Wydawnictwo Wawelskie, 1994.

KopALIŃSKI, Władysław. Stownik symboli. Warszawa: Wiedza Powszechna, 1990.

KowAlski, Piotr. Chleb nasz powszedni. O pieczywie w obrzędach, magii, literackich obrazach i opiniach dietetyków. Wrocław: Towarzystwo Przyjaciół Ossolineum, 2000.

\footnotetext{
${ }^{55}$ Dzierzążnia, T.K., kobieta, ur. 1935 r.
} 
ŁOPACIŃSKI, Hieronim. „Obrzędy religijne i zwyczaje przy nich zachowane. Z materiałów nadesłanych na Wystawę rolno-przemysłową w 1901". Wisła 16, z. 3 (1902): 358-363.

MAJ, Małgorzata. Rola daru w obrzędzie weselnym. Wrocław-Warszawa-Kraków-GdańskŁódź: Ossolineum, 1986.

Mauss, Marcel. Socjologia i antropologia. Przełożyli Marcin Król, Krzysztof Pomian, Józef Szacki. Warszawa: PWN, 1973.

MoszyŃSKi, Kazimierz. Kultura ludowa Stowian. T. II cz. 1. Kraków: Książka i Wiedza, 1967.

Ogrodowska, Barbara. Polskie tradycje i obyczaje rodzinne. Warszawa: Wydawnictwo Muza, 2007.

Pranke, Piotr. „Dar”. W Przeszłość społeczna. Próba konceptualizacji, red. Stanisław Tabaczyński, Arkadiusz Marciniak, Dorota Cyngot, Anna Zalewska, 783-790. Poznań: Wydawnictwo Poznańskie, 2012.

SikorA, Kazimierz. „Winszowanie i dobre słowo w gwarze”. Annales Universitatis Paedagogicae Cracoviensis Studia Linguistica 107, nr 6 (2011): 171-189.

Stownik stereotypów i symboli ludowych, red. Jerzy Bartmiński. T. 2: Rośliny, cz. 2: Warzywa, 282-294. Lublin: Wydawnictwo UMCS, 2018.

STANisZeWska, Zofia. „Wieś Studzianki”. Wista 16, z. 4 (1902): 490-505.

SzROMBA-RYSOwA, Zofia. „Zwyczaje towarzyskie, zawodowe i okolicznościowe”. W Etnografia Polski. Przemiany kultury ludowej, t. II, 155-160, red. Maria Biernacka, Bronisława Kopczyńska-Jaworska, Anna Kutrzeba-Pojnarowa, Wanda Paprocka. Wrocław: Ossolineum, 1981.

Szromba-Rysowa, Zofia. „Biesiady wiejskie”. Etnografia Polska 28, z. 1 (1984): 105-131.

Tyмосноwicz, Mariola. Lubelska obrzędowość rodzinna w kontekście współczesnych przemian. Lublin: Lubelskie Towarzystwo Naukowe, 2013.

ZADROŻYŃSKA, Anna. Światy, zaświaty. O tradycji świętowań polskich. Warszawa: Wydawnictwo Książkowe Twój Styl, 2000.

ŽAJVORONOK, Vitalij. Znaki ukrajins'koji etnokul'turi. Slovnik-dovidnik. Kijiv, 2006.

\section{DAR W OBRZĘDZIE NARODZINOWYM NA LUBELSZCZYŹNIE}

\section{Streszczenie}

Obdarowywanie w obrzędzie narodzinowym w przeszłości jak i współcześnie odgrywa ważną rolę, stanowi jeden z istotniejszych jego elementów. W artykule przedstawione zostały sytuacje, w których dochodziło do składania darów, kto był obdarowywany i jakie były i są obecnie formy darów, a także jakie one mają znaczenie. Podstawę analizy stanowią etnograficzne materiały z terenu Lubelszczyzny zastane i wywołane, pozyskane przez autorkę, jak też pochodzące $\mathrm{z}$ archiwów lubelskich muzeów i Archiwum Polskiego Atlasu Etnograficznego z Cieszyna.

Slowa kluczowe: obrzęd narodzinowy; dar; kultura tradycyjna i współczesna. 